\title{
Implementasi Location Based Service pada Sistem Informasi Kehadiran Pegawai Berbasis Android
}

\author{
Naviza Qois, Yuwan Jumaryadi* \\ Program Studi Sistem Informasi, Fakultas Ilmu Komputer, Universitas Mercu Buana, \\ Jl. Raya Meruya Selatan, Kec. Kembangan, Daerah Khusus Ibukota Jakarta 11650 \\ *e-mail: yuwan.jumaryadi@ mercubuana.ac.id
}

(received: 5 April 2021, revised: 22 Juni 2021, accepted: 11 Juli 2021)

\begin{abstract}
Abstrak
Seiring dengan perkembangan teknologi yang begitu cepat serta pengembangan berbagai aplikasi pada smartphone yang bertujuan untuk kemudahan dan kenyamanan pengguna, khususnya pada masa pandemic COVID-19 saat ini dimana banyak perusahaan yang melakukan kebijakan work from home (WFH), pegawai yang melakukan kerja lapangan dan pegawai dinas luar kota. Sehingga terjadi masalah terhadap absensi kehadiran pegawai karena biasanya proses absensi dilakukan di kantor. Bagaimanapun, absensi merupakan indikator utama dalam penilaian pegawai. Sehingga diperlukan sebuah aplikasi mobile yang dapat digunakan pegawai dalam melakukan absensi kehadiran tanpa perlu datang ke kantor. Tujuan dari penelitian ini adalah untuk mendapatkan laporan absensi secara realtime dan disertai dengan koordinaat pegawai saat absensi, validasi yang digunakan dengan melakukan foto selfie wajah pegawai dan validasi atasan terhadap daily timesheet yang diberikan melalui aplikasi. Pengembangan aplikasi ini menggunakan metodologi waterfall. Metodologi waterfall memiliki 5 tahapan yaitu Communication, Planning, Modeling, Construction, dan Deployment. Sedangkan untuk metode pengujian yang digunakan dalam penelitian ini adalah black box dan usability testing. Sistem yang dikembangkan dalam penelitian ini dapat digunakan ketika karyawan melakukan absensi saat mereka bekerja dari rumah, kerja lapangan atau dinas ke luar kota. Dengan menggunakan teknologi GPS, maka HRD dapat mengetahui lokasi karyawan ketika melakukan absensi.
\end{abstract}

Kata kunci: kehadiran, foto, report, mobile, pegawai

\begin{abstract}
Along with the rapid development of technology and the development of various applications on smartphones aimed at the convenience and comfort of users, especially during the current COVID-19 pandemic where many companies are implementing work from home (WFH) policies, employees who do field work and employees out of town duty. So that there is a problem with employee attendance because usually the attendance process is carried out in the office. However, absenteeism is the main indicator in employee appraisal. So we need a mobile application that can be used by employees in carrying out attendance without the need to come to the office. The purpose of this study is to obtain real-time attendance reports accompanied by employee coordinates during attendance, validation used by taking selfies of employees' faces and supervisor validation of the daily timesheet provided through the application. The development of this application uses the waterfall methodology. The waterfall methodology has 5 stages, namely Communication, Planning, Modeling, Construction, and Deployment. Meanwhile, the testing method used in this research is black box and usability testing. The system developed in this study can be used when employees take attendance when they work from home, field work or work out of town. By using GPS technology, HRD can find out the location of employees when doing attendance.
\end{abstract}

Keywords: attendance, photo, report, mobile, employee 


\section{Pendahuluan}

Seiring dengan perkembangan teknologi yang begitu cepat serta pengembangan berbagai aplikasi pada smartphone yang bertujuan untuk kemudahan dan kenyamanan pengguna dalam membantu pekerjaan maupun aktivitas serta komunikasi [1]. Dalam sebuah perusahaan terdapat KPI (Key Performance Indicator) untuk mengukur performansi kerja pegawai, parameter perhitungan performansi pada perusahaan satu dan lainnya berbeda. Salah satu kinerja yang umumnya penting dipantau oleh perusahaan adalah disiplin kehadiran jam kerja sehingga digunakan sebagai indicator performansi [2]. Pada masa pandemic COVID-19 saat ini banyak perusahaan yang melakukan kebijakan work from home (WFH) yang mana pegawai melakukan pekerjaan dari rumah atau remote. [3] Menanggapi masalah yang terjadi maka diperlukan sebuah sistem yang dapat memenuhi sarana informasi kehadiran, memberikan visibilitas terhadap kinerja setiap pegawai serta dapat membantu agar pegawai dapat melakukan absensi melalui smartphone dan mengerjakan task yang diberikan dari atasan sebagai validasi atas kinerja yang telah dilakukan [4].

Sistem pencatatan kehadiran yang tengah berjalan saat ini dilakukan pegawai melalui group chat dengan mengupdate task yang akan dikerjakan. Karena pegawai WFH yang melakukan laporan kehadiran melalui aplikasi chat dianggap menjadi kurang praktis. HR diharuskan melakukan rekap secara manual setiap pegawai untuk dilakukan penilaian terhadap performa kerja. Selain itu perusahaan kesulitan dalam mengetahui lokasi keberadaan pegawai, mengontrol dan monitoring untuk menentukan kehadiran pegawai apakah sudah memenuhi kewajibannya. Berdasarkan permasalahan tersebut, maka diperlukan sebuah sistem aplikasi kehadiran yang dapat digunakan untuk membantu proses absensi pegawai yang melakukan Work From Home (WFH). HRD dapat mengolah data absensi kehadiran dengan mengetahui lokasi pegawai, atasan dapat melakukan validasi terhadap kehadiran serta kinerja pegawai, dan sistem dapat mengolah data menjadi laporan yang dapat membantu peerusahaan mengetahui aktifitas dan performa pegawai. Dengan adanya permasalahan tersebut peneliti menganggap bahwa solusi terhadap permasalahan tersebut adalahan pengembangan sistem absensi untuk kehadiran pegawai. Metodologi yang digunakan untuk pengembangan sistem adalah waterfall, dimana metodologi pengembangan waterfall memiliki 5 tahapan, yaitu Communication, Planning, Modeling, Construction, dan Deployment. [5]

Saat ini smartphone sudah banyak dimiliki oleh masyarakat luas sehingga aplikasi berbasis android dapat digunakan oleh masing-masing pegawai untuk melakukan absensi datang dan pulang dimana saja dan kapanpun. Tujuan dari sistem yang dibangun adalah untuk membantu pegawai dalam melakukan kehadiran dengan smartphone yang menjadi alat absensi atau pengganti mesin absensi. Ketika pegawai melakukan absensi di aplikasi maka sistem dapat mencatat lokasi dan tracking location realtime menggunakan location based service yang dapat mengkonversi koordinat menjadi sebuah alamat[6]. Sehingga perusahaan bisa mendapatkan laporan kehadiran sesuai data yang diperlukan beserta current location setiap pegawai. Selain itu kehadiran pegawai di validasi dengan pengerjaan oleh pegawai [7]. Manfaat dari sistem ini adalah perusahaan mendapatkan laporan sesuai data yang diperlukan dan memberikan visibilitas kinerja pegawai yang melakukan WFH atau kerja dari rumah sehingga perusahaan dapat mengukur performa pegawai.

\section{Tinjauan Literatur}

Berbagai hasil penelitian sebelumnya yang berkaitan dengan kehadiran, absensi, ataupun presensi yang dipadukan dengan perangkat dan metode berbeda dilakukan pada penelitian sebelumnya, sehingga dengan adanya ihtisar penelitian sebelumnya memberikan kontribusi masingmasing terhadap sistem yang dihasilkan. Absensi kehadiran merupakan pencatatan terhadap datang dan pulang pegawai. Perusahaan melakukan pencatatan terhadap kehadiran pegawai sebagai salah satu indikator penilaian performance dan kedisiplinan serta tanggung jawab terhadap pekerjaan. Dengan memanfaatkan teknologi yang terus berkembang data kehadiran dapat diolah dalam suatu sistem sehingga report menjadi lebih akurat dan memudahkan perusahaan untuk melakukan review kehadiran pegawai menggunakan periode, nama, dan bagian yang diperlukan [8].

Berdasarkan penelitian yang dilakukan oleh Hermanto, dkk [9], salah satu cara untuk memvalidasi kehadiran mahasiswa pada kegiatan perkuliahan secara manual yaitu dengan memanggil mahasiswa satu per satu, sehingga memerlukan proses yang lama dan dosen perlu merekap secara manual. Dari permasalahan tersebut dikembangkan aplikasi sistem presensi mahasiswa berbasis 
android dengan menggunakan QR Code sebagai alat untuk merekam data kehadiran mahasiswa secara cepat, dosen dapat mengetahui rekap kehadiran mahasiswa setiap selesai perkuliahan. Metode penelitian ini menggunakan metode pengembangan waterfall. Pada saat mahasiswa mendaftar secara otomatis sistem akan menyimpan IMEI dari HP mahasiswa, hal ini ditujukan agar satu mahasiswa memiliki satu akun yang tidak dapat dipinjam dan juga digunakan untuk menghindari titip absen dan sistem juga memberikan rekap kehadiran mahasiswa secara keseluruhan. Sistem dan aplikasi ini juga telah diimplementasikan dalam perkuliahan dan membantu dosen dalam proses presensi dan rekap kehadiran mahasiswa yang nantinya akan dijadikan salah satu indikator penilaian dalam proses perkuliahan.

Berdasarkan penelitian yang dilakukan oleh Sasongko, dkk [10], presensi kehadiran karyawan akan ditransformasikan menjadi aplikasi mobile. Hal ini dilakukan untuk menghindari keterlambatan dalam antrian tunggu pada proses web dan menghindari kecurangan titip absen yang dapat dilakukan oleh karyawan ketika melakukan presensi. Aplikasi mobile menggunakan Nomor Induk Karyawan (NIK) dan IMEI handphone dan terhubung dengan database serta server web perusahaan sehingga mempermudah untuk mendapatkan data presensi karyawan. Berdasarkan hasil uji, waktu memuat data yang berjenis JSON dari aplikasi mobile dapat diakses dalam waktu akses rata-rata 0.83 milisecond, sehingga tidak ada hambatan dalam penerapan aplikasi ini secara luas.

Selanjutnya penelitian yang dilakukan oleh Radityatama, dkk [11], menggunakan Microcontroller untuk perancangan smart indicator lecturer berbasis Android menggunakan fingerprint dosen. Dosen melakukan scan fingerprint dengan microcontroller setelah mendapat ID dan dosen melakukan absen kehadiran maka data kehadiran dikirimkan ke firebase, firebase mengirim data ke smartphone user. Berdasarkan hasil pengujian yang dilakukan dalam penelitian ini, tingkat keberhasilan presensi dapat terbaca oleh sistem sebesar 88,6\%.

Dalam penelitian yang dilakukan oleh Adikara, dkk [3], dikembangkan sistem kehadiran karyawan berbasis android 4.x dengan Global Postioning Sistem (GPS) untuk mendapatkan lokasi karyawan yang sedang melakukan dinas luar. Karyawan yang melakukan dinas luar menggunakan aplikasi ini dengan register menggunakan NIP, nama dan password. Setelah melakukan register maka karyawan dapat login ke aplikasi absensi, pada saaat absen user diminta memasukkan ID. Setelah di simpan maka sistem mencatat waktu, tanggal, dan koordinat lokasi karyawan tersebut. Data dikirim ke server dan tersimpan di database sistem, data ini nantinya dapat digunakan perusahaan untuk mengetahui kehadiran dan lokasi keberadaan karyawan.

Dalam penelitian yang dilakukan oleh Husain, dkk [7], dikembangkan sistem kehadiran karyawan berbasis mobile android yang dapat mempercepat dan memudahkan karyawan dalam melakukan absensi tanpa harus mengantri didepan mesin absensi. Karyawan menggunakan aplikasi absensi di handphone masing-masing dan, maka halaman menampilkan button absen untuk melakukan absen datang dan pulang, data absen dikirim keserver dan database sehingga HRD mendapatkan data absensi karyawan. Dengan sistem ini perusahaan dapat dengan mudah mengolah data absensi dengan mudah dan mempercepat absensi maka waktu yang dibutuhkan dalam bekerja juga sangat efisien.

Dalam penelitian yang dilakukan oleh Sunarya, dkk [12], menyajikan sistem kehadiran dan cuti berbasis mobile android dan GPS. Karyawan dapat melakukan absen dan mengajukan cuti melalui aplikasi mobile sehingga mempermudah proses cuti. Sistem yang dikembangkan ini menggunakan GPS dan sistem login dengan ID karyawan untuk menghindari double data atau redundancy pada sistem. Pada saat melakukan absensi sistem menyimpan data lokasi berupa alamat, tanggal dan waktu. Selain itu kelebihan pada sistem ini karyawan dapat menambahkan pesan dan disediakan button untuk melihat koordinat karyawan melalui map.

Berdasarkan beberapa penelitian tentang pengembangan sistem kehadiran, sistem kehadiran dapat membantu karyawan dalam melakukan absensi. Pada penelitian ini akan dikembangkan sistem absensi dengan menggunakan fitur Location Based Service (LBS) dan juga dengan menambahkan fitur task, sehingga atasan (leader) dapat ikut memvalidasi kehadiran karyawan berdasarkaan task yang telah dikerjakan oleh karyawan. Dengan adanya penambahan fitur ini maka dapat mengurangi kecurangan maupun kelalaian dalam mengerjakan tanggung jawab terhadap perusahaan [13]. Pada saat karyawan melakukan aktivitas di aplikasi, sistem mengupdate data secara realtime menggunakan APIs yang terhubung langsung dengan database. API bertujuan untuk menghubungkan aplikasi mobile dengan database yang ada di dalam server. API ini nantinya untuk memenuhi seluruh jenis 
fungsi yang dibutuhkan di dalam aplikasi. Seperti fungsi tampil item, fungsi edit item, fungsi POST transaksi, dan lain sebagainya. [14]

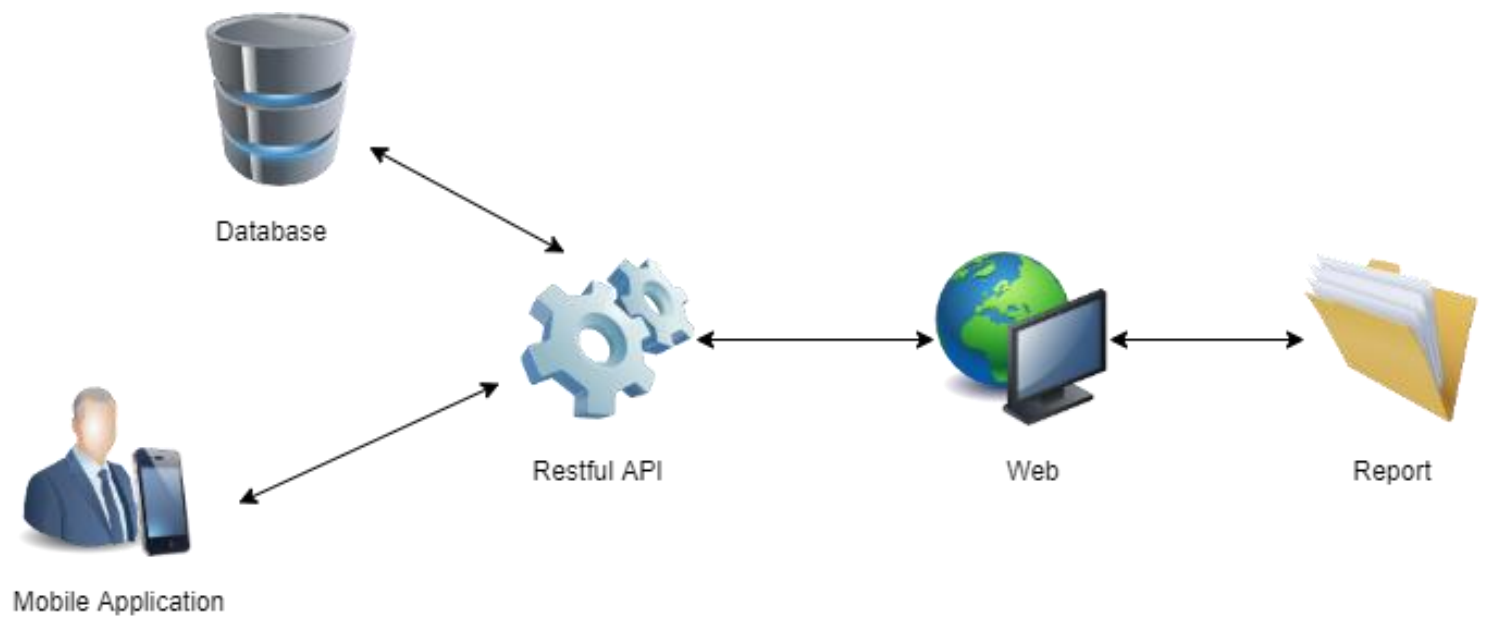

Gambar 1. Konsep Sistem Kehadiran Menggunakan API

Penelitian ini menggunakan GPS untuk mendapatkan lokasi kehadiran dari absensi yang dilakukan karyawan berupa koordinat longitude dan latitude, peneliti melakukan konversi koordinat ini menggunakan location based service (LBS) menjadi sebuah alamat [15]. Location based service (LBS) merupakan salah satu layanan informasi yang memanfaatkan kemampuan penunjuk lokasi pada perangkat mobile dan dapat diakses melalui jaringan mobile. Pada Android Studio LBS menggunakan geocoder sebagai pendukung untuk mengetahui lokasi user secara realtime. Dengan menggunakan geocoder ini letak koordinat yang berupa latitude dan longitude dapat dikonversi menjadi sebuah alamat yang dapat dibaca dan diketahui letak atau posisinya. Mobile apps yang menggunakan metode ini dapat dilakukan tracking lokasi secara realtime.

\section{Metode Penelitian}

Pada penelitian ini peneliti menggunakan metode pengembangan waterfall. Waterfall merupakan pengembangan perangkat lunak yang dimulai dengan spesifikasi persyaratan dan kemajuan melalui perencanaan, pemodelan, konstruksi, dan pengembangan, yang berpuncak pada dukungan berkelanjutan untuk penyelesaian perangkat lunak [16].

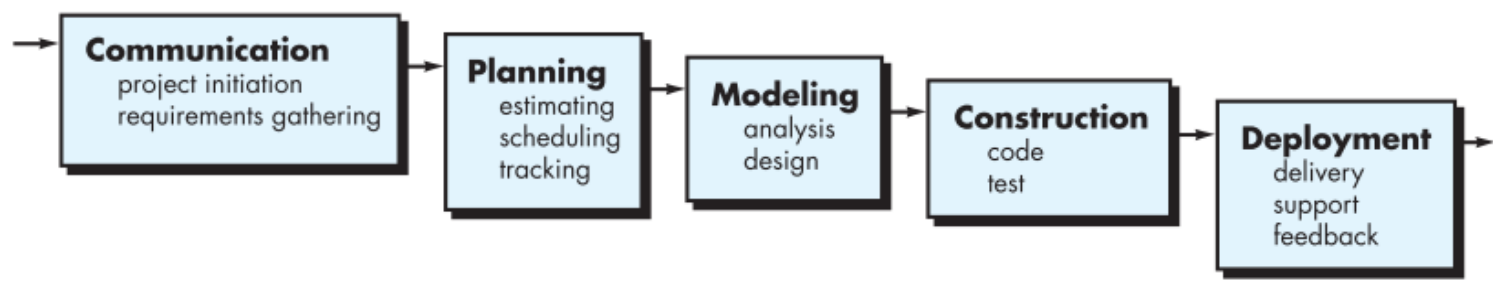

\section{Gambar 2. Siklus Pengembangan Sistem Informasi}

Berdasarkan gambar 2 diatas, metode waterfall memiliki 5 tahapan, yaitu:

1. Tahap Communication (Project Initiation \& Requirements Gathering)

Pada tahapan ini peneliti melakukan wawancara terhadap HRD dan karyawan mengenai sistem kehadiran absensi yang sudah berjalan selama WFH. Selain itu, peneliti melakukan observasi dan pengumpulan data yang diperlukan untuk kebutuhan sistem.

2. Tahap Planning (Estimating, Scheduling, Tracking)

Pada tahapan ini dilakukan pembuatan jadwal terhadap perancangan sebagai acuan dalam pengembangan aplikasi. Penjadwalan yang dibuat nantinya diharapkan dapat menjadi panduan dalam penelitian yang dilakukan. 
3. $\quad$ Modeling (Analysis \& Design)

Pada tahapan ini dilakukan pembuatan rancangan antar muka sesuai tahapan design yang telah dilakukan dengan menggunakan Unified Modeling Language (UML). Setelah pembuatan UML telah selesai, kemudian pembuatan coding untuk pengembangan aplikasi berdasarkan perancangan yang telah dibuat.

4. Construction (Code \& Test)

Setelah melakukan pengembangan sistem, maka sistem akan diuji terlebih dahulu. Proses pengujian ini dilakukan untuk memastikan bahwa pengembangan sistem telah sesuai dengan kebutuhan user. Pada pengujian ini dilakukan 2 metode testing, yaitu black box testing dan usabilitiy testing. Black box testing dilakukan dengan berfokus pada fungsionalitas dari sistem, dan usability testing dilakukan dengan memberikan kuesioner menggunakan google form terhadap karyawan yang akan menggunakan sistem.

5. Deployment (Delivery, Support, Feedback)

Tahap akhir dari metode ini adalah pemeliharaan sistem. Pemeliharaan sistem dilakukan pada sistem yang sudah diimplementasikan. Jika terdapat error terhadap sistem yang telah dikembangkan maka akan dilakukan perbaikan terhadap error yang ada.

\section{Hasil dan Pembahasan}

Dalam implementasi sistem kehadiran pegawai diperlukan interface antara sistem web kehadiran dengan aplikasi mobile. Perusahaan dapat menggunakan sistem web kehadiran untuk memaintain data dan juga laporan dari aktivitas transaksi pegawai di aplikasi mobile kehadiran.

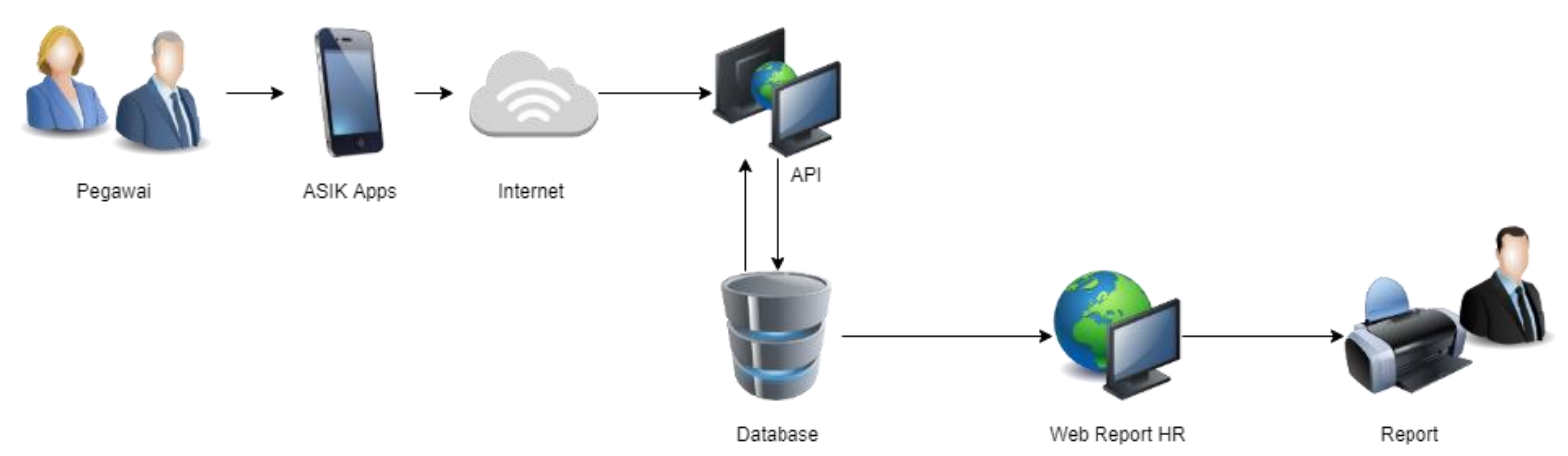

Gambar 3. Mekanisme Absensi Pegawai

Pada gambar 3 diatas merupakan mekanisme absensi pegawai melalui aplikasi mobile yaitu: 1) pegawai melakukan install aplikasi absensi di android phone masing-masing dan terhubung dengan internet. 2) melakukan absensi maka data tersimpan di database, pada bagian web HR dapat melakukan rekap laporan otomatis sesuai dengan transsaksi yang dilakukan oleh pegawai.

\subsection{Perancangan Sistem}

Pada Gambar 4 dibawah ini merupakan use case diagram untuk sistem kehadiran pegawai. 


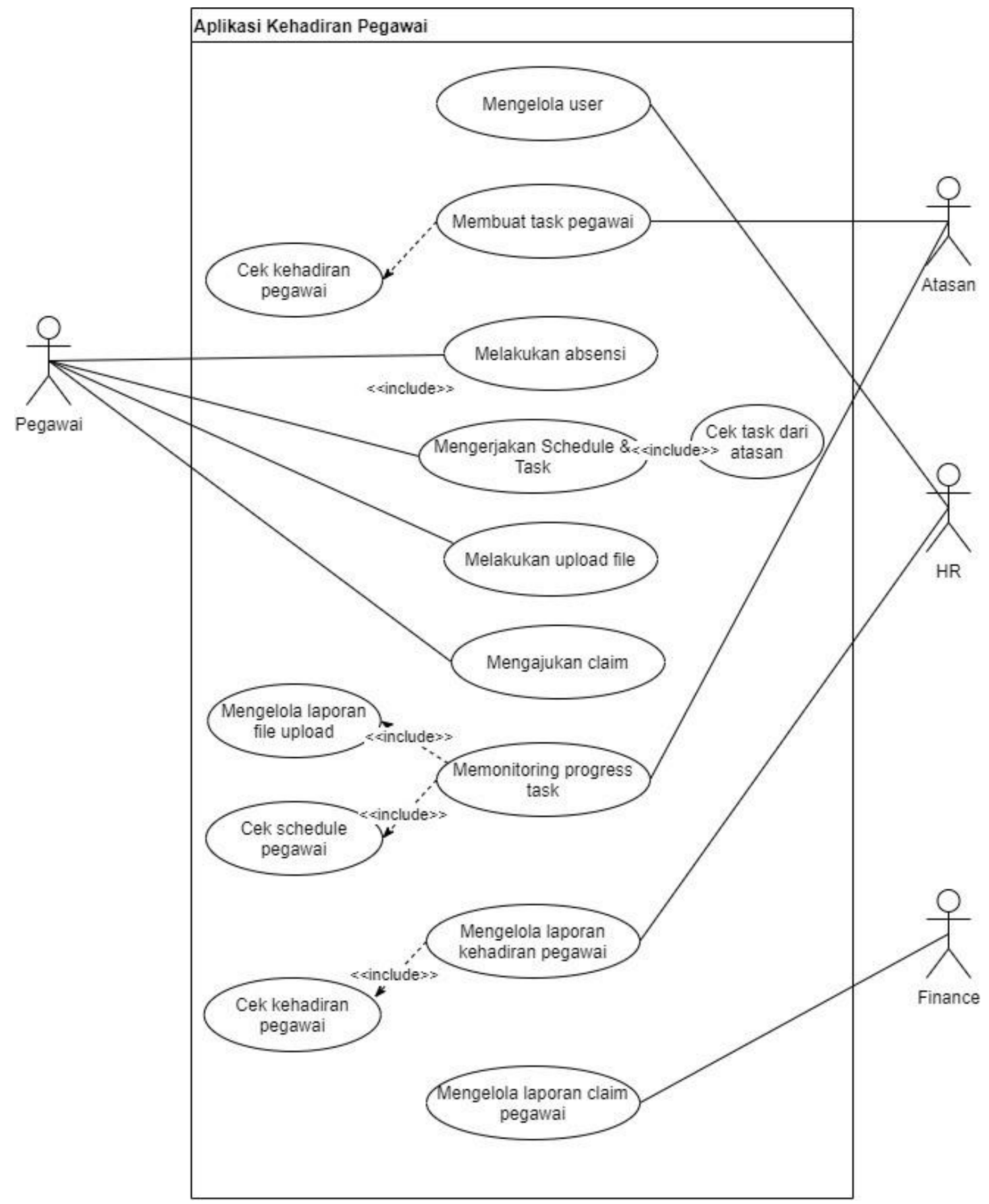

\section{Gambar 4. Use Case Diagram Sistem Informasi Apikasi Kehadiran Pegawai}

Berdasarkan gambar 4 diatas, ada 4 aktor pada sistem yang akan dikembangkan yaitu Finance, HR, Atasan, dan Pegawai. HR dapat melakukan pengelolaan terhadap user, dan juga mengelola laporan kehadiran pegawai. Setelah itu atasan dapat membuat task pegawai, dan melakukan monitoring terhadapnya. Kemudian pegawai dapat mengerjakan schedule dan task yang diberikan, melakukan upload file terhadap hasil pekerjaannya, melakukan absensi dan mengajukan claim. Kemudian Finance dapat mengelola laporan claim dari pegawai

\subsection{Implementasi \& Pengujian}

\section{A. Aplikasi Mobile - Home}

Setelah user melakukan login maka sistem menampilkan halaman home. Halaman ini menampilkan nama dan jabatan pegawai sesuai dengan data yang diinput pada sistem, selain itu halaman ini menampilkan activity menu yang dapat diakses oleh pegawai. 


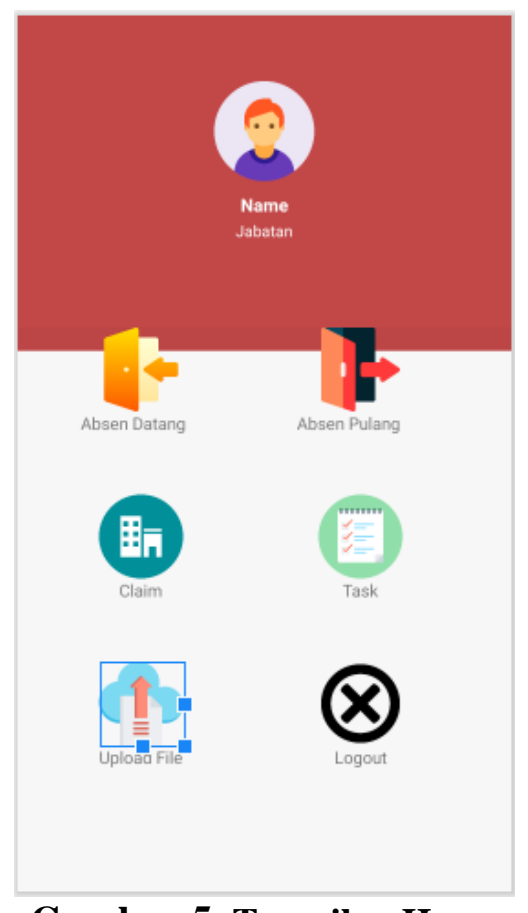

\section{Gambar 5. Tampilan Home}

Pada gambar 5 merupakan halaman home pada aplikasi mobile. Pada halaman ini terdapat profile pegawai yang menampilkan nama dan jabatan. Halaman home ini menampilkan menu absen datang, absen pulang, task, dan claim.

\section{B. Aplikasi Mobile - Absen}

Pegawai melakukan login di aplikasi mobile dan melakukan absensi kehadiran datang dan pulang dengan menu absen datang dan pulang. Ketika pegawai masuk pada menu absensi maka sistem mencatat tanggal, jam dan koordinat lokasi pegawai pada saat melakukan aktivitas di menu absen.
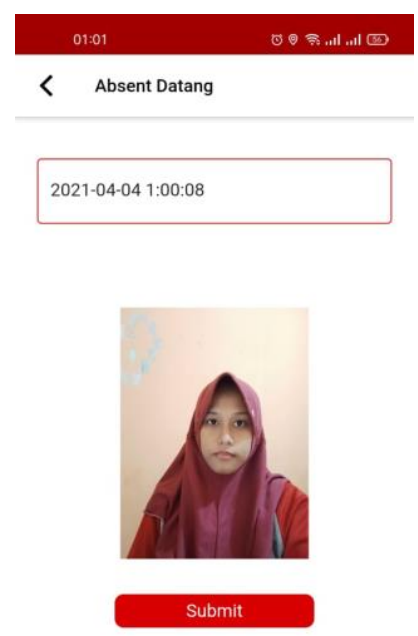

Gambar 6. Form Absensi Mobile 
Pada gambar 6 menampilkan halaman menu absensi datang, sistem menampilkan informasi tanggal dan waktu secara realtime. Pada saat melakukan absensi wajib mengambil foto selfie yang menunjukkan wajah pegawai, setelah foto sistem menampilkan preview foto dan klik button submit untuk menyimpan data tanggal, waktu dan koordinat pada saat absen dilakukan. Aktivitas absen ini nanti sistem dapat mengetahui lokasi absen pegawai tersebut.

\section{Web - Report Claim}

Halaman report claim dapat diakses oleh finance untuk mendapatkan laporan claim pegawai dari aktivitas input data di aplikasi mobile.

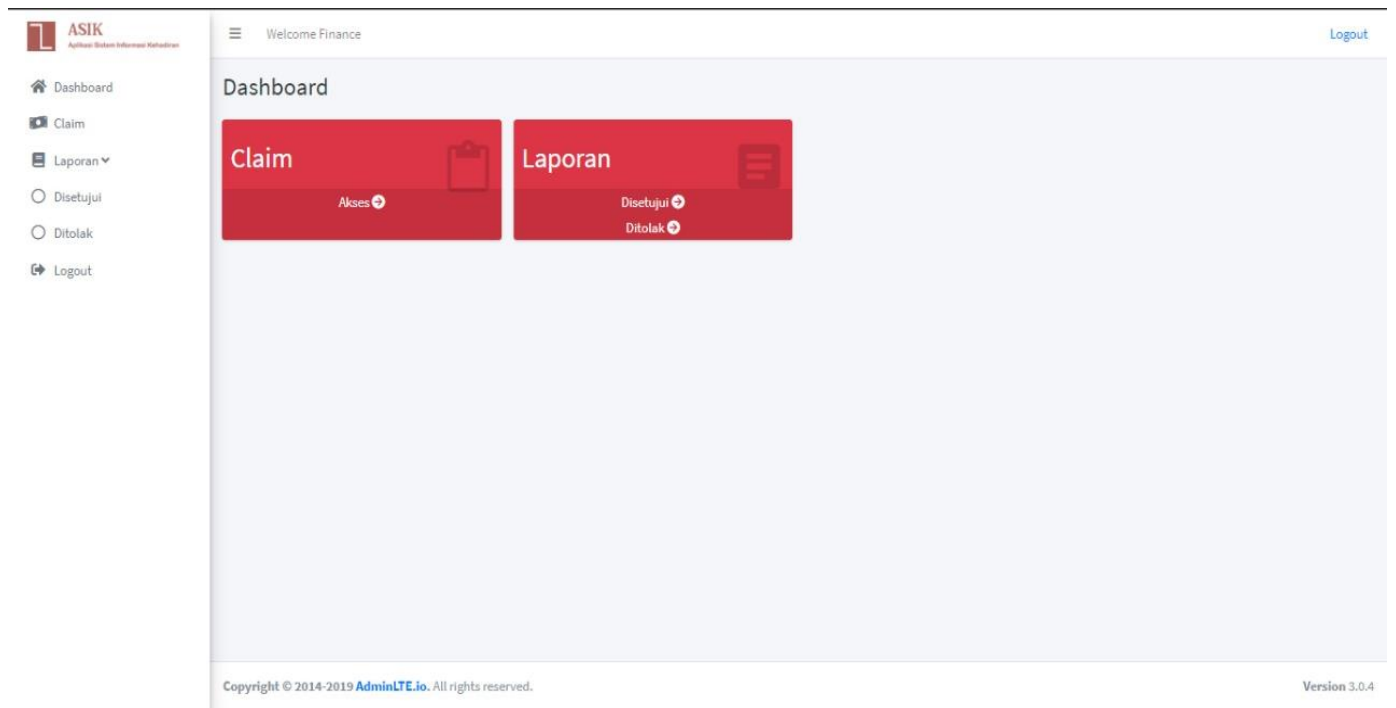

Gambar 7. Halaman Utama Finance

Gambar 7 menampilkan halaman utama jika login sebagai finance. Pada halaman ini finance dapat melihat data report claim dari pegawai yang dilakukan di aplikasi mobile. Selain itu, finance juga dapat melakukan export data ke excel dan mengolah data sesuai dengan kebutuhan.

\section{Web - Report Absen}

Halaman ini dapat diakses oleh HRD untuk register atau menambah data peagawai mapun akses untuk aplikasi mobile dan web.

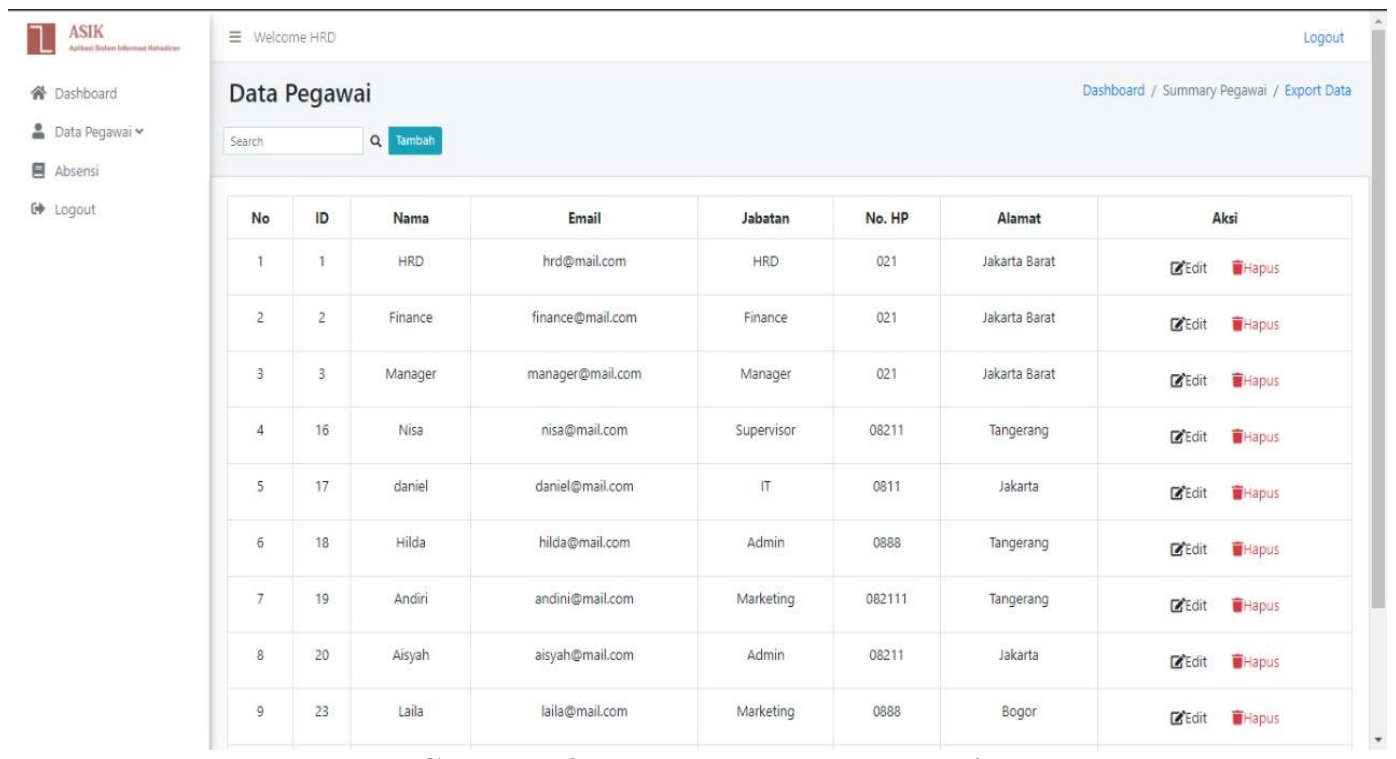

Gambar 8. Halaman Data pegawai 
Pada Gambar 8 merupakan halaman data pegawai. Pada halaman ini HRD dapat melakukan aktivitas add new data pegawai dan registrasi untuk menambahkan role user pegawai, melakukan edit untuk mengubah data dan delete untuk menghapus data pegawai. Halaman data pegawai dapat di export dalam bentuk excel yang dapat digunakan untuk memelihara dan mengolah data sesuai kebutuhan.

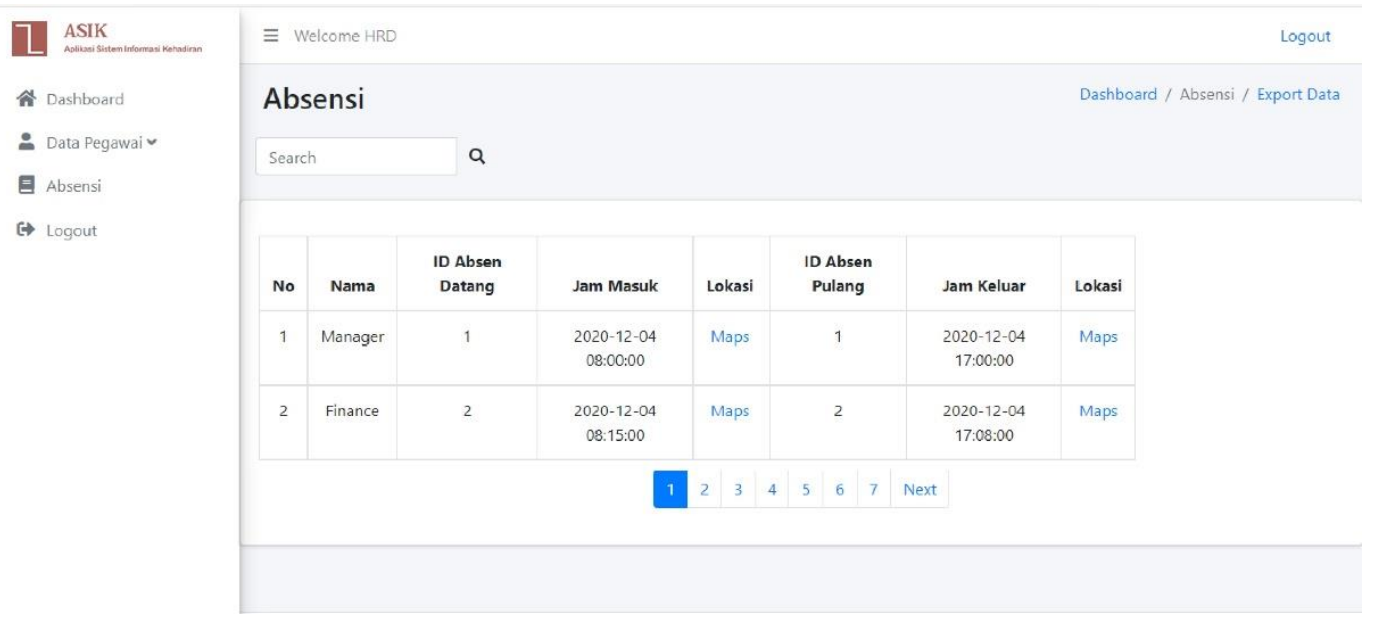

Gambar 9. Report Absensi

Pada Gambar 9 menampilkan halaman absensi, HRD dapat melihat report kehadiran absensi pegawai yang dilakukan di aplikasi mobile. Pada halaman ini, HRD dapat melihat lokasi dari karyawan ketika melakukan absensi. Lokasi karyawan diambil berdasarkan koordinat GPS ketika karyawan melakukan absensi melalui aplikasi mobile. Halaman Report absensi ini juga dapat diekspor menjadi file excel yang dapat diolah sebagai bahan penilaian kinerja pegawai.

\section{E. Testing}

\section{Usability Testing}

Pengujian usabilitas juga telah dilakukan untuk mengetahui kesesuaian sistem yang telah dibangun dengan kebutuhan user [17]. Pengujian usabilitas dilakukan dengan memberikan kuesioner https://docs.google.com/forms/d/1ZCfcL-H KvChFebu VmDxRXY4FMt1bxm3IosEKB7cOU/viewform? edit requested=true kepada pengguna dengan menggunakan Skala Likert. Hasil kuesioner yang didapatkan dengan menggunakan standar kuesioner SUS adalah 60. Hal ini menunjukkan bahwa sistem yang dikembangkan berada pada kategori "OK", akan tetapi nilai tersebut berada pada grade D [18]. Selain itu, berdasarkan hasil kuesioner usabilitas pengembangan dan perbaikan terhadap fungsionalitas sistem masih perlu dilakukan, dan juga diperlukan sosialisasi mengenai penggunaan sistem, baik itu berupa video tutorial atau manual book.

Tabel 1. Kuesioner SUS

\begin{tabular}{llcc}
\hline \multicolumn{1}{c}{ Pernyataan } & Rata-rata & Kategori \\
\hline 1. & Saya merasa bahwa saya akan lebih sering menggunakan ASIK & 3.8 & Setuju \\
2. Saya menilai bahwa seharusnya ASIK tidak perlu serumit ini & 2.85 & Netral \\
3. Saya menilai bahwa ASIK mudah untuk digunakan & 4.05 & Setuju \\
4. Saya merasa bahwa saya akan memerlukan bantuan dari orang teknis & 2.65 & Netral \\
$\quad \begin{array}{l}\text { agar dapat menggunakan ASIK } \\
\text { 5. Saya menilai bahwa beberapa fungsi dari ASIK telah terintegrasi }\end{array}$ & 3.8 & Setuju \\
$\quad \begin{array}{l}\text { dengan baik } \\
\text { 6. Saya merasa bahwa banyak ketidakkonsistenan dalam ASIK }\end{array}$ & 2.75 & Netral \\
7. Saya merasa bahwa ASIK dapat dipelajari oleh sebagian besar orang & 3.85 & Setuju \\
& & & http://sistemasi.ftik.unisi.ac.id
\end{tabular}




\begin{tabular}{llcc}
\hline 8. Saya menilai bahwa ASIK sangat rumit untuk digunakan & 2.25 & Tidak Setuju \\
9. Saya merasa sangat percaya diri untuk menggunakan ASIK & 3.95 & Setuju \\
10. Saya merasa perlu belajar banyak hal sebelum memulai & 2.75 & Netral \\
menggunakan ASIK & & \\
\hline
\end{tabular}

\section{Black Box Testing}

Berikut ini merupakan pengujian (Testing) yang dilakukan dengan menggunakan metode black box testing terhadap sistem informasi yang dikembangkan. Tabel 1 dibawah merupakan hasil pengujian black box.

Tabel 2. Hasil Pengujian Black Box Testing

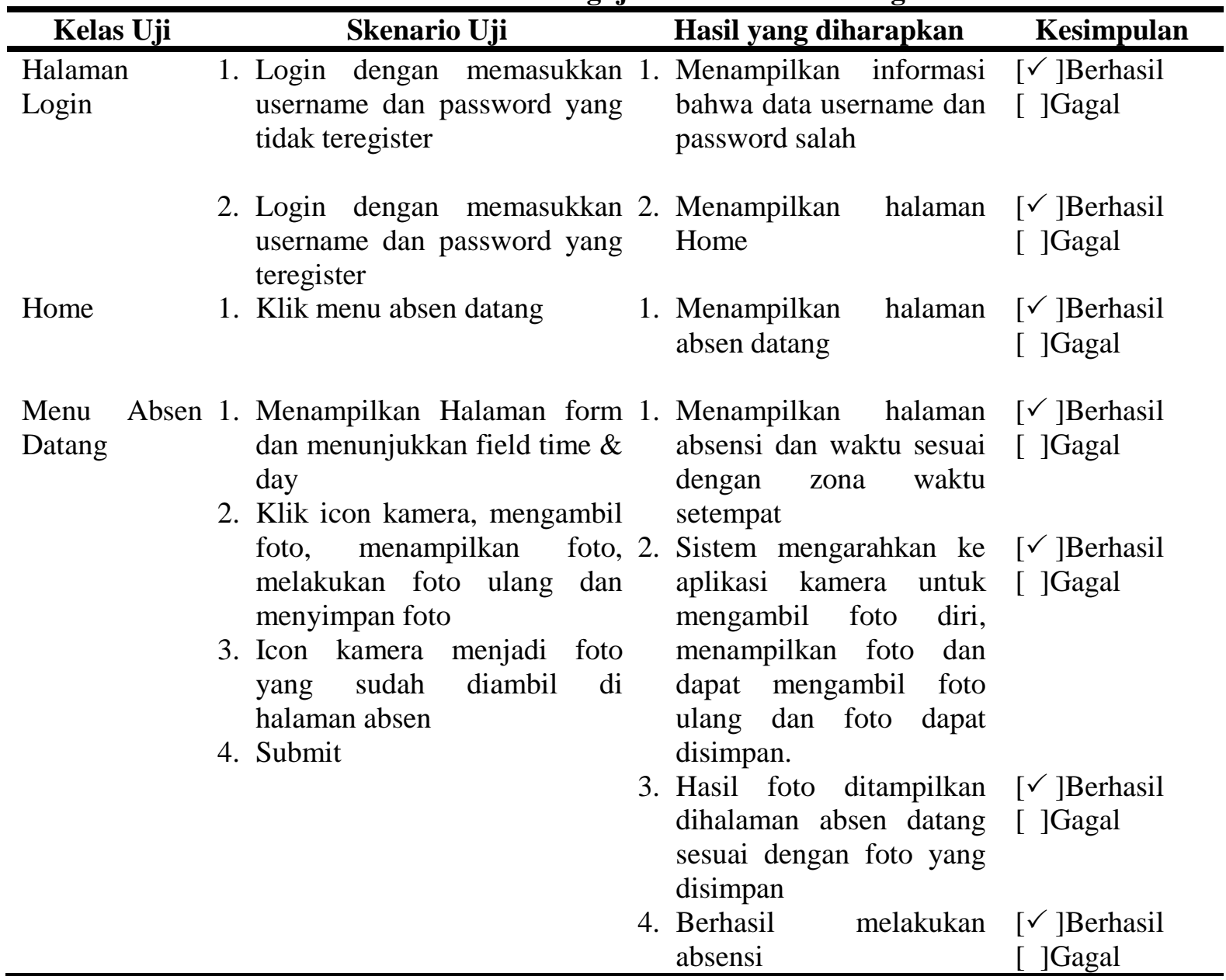

\section{Kesimpulan}

Dengan mengambil koordinat karyawan ketika melakukan absensi, HRD dapat mengetahui lokasi karyawan ketika melakukan absensi, selain itu juga HRD tidak perlu melakukan manual reporting untuk mendapatkan absensi kehadiran pegawai. Pada sistem sudah dilakukan registrasi user login sesuai dengan user privilege, sehingga user dapat melakukan login di sistem sesuai dengan role masing-masing. Pegawai yang melakukan WFH dapat menggunakan aplikasi mobile untuk melakukan absensi kehadiran, melakukan update schedule dan mengerjakan task dari atasan. Berdasarkan penelitian yang dilakukan oleh ananta, dkk [19], proses validasi yang dilakukan lebih dari 1 kali dapat mengurangi tindak kecurangan dalam absensi, sedangkan dalam penelitian yang dilakukan terdapat dua kali validasi, pertama yaitu ketika melakukan absensi dengan mengirimkan koordinat GPS dan juga menginput task list yang akan divalidasi oleh atasan sebagai report pegawai yang melakukan WFH. Selain itu, task list yang divalidasi oleh atasan dapat menjadi indikator dalam 
menilai performa karyawan. Apabila banyak list pekerjaan yang masih belum selesai dikerjakan oleh karyawan, maka akan mempengaruhi performa karyawan tersebut.

\section{Referensi}

[1] B. Priambodo, N. Ani, and Y. Jumaryadi, "An efficient and affordable push strategy of mobile advertising for micro enterprises," Internetworking Indones. J., vol. 10, no. 2, pp. 43-48, 2018.

[2] I. P. Wulandari, Setyaningsih, W. L. Setyaningsih, A. P. W. Wardhana, and Y. Jumaryadi, "Implementasi Metode SCOR 11.0 dalam Pengukuran Kinerja Supply Chain Management Indah,” Sistemasi, vol. 10, no. 1, pp. 106-121, 2021.

[3] F. Adikara, "Analisis Dan Perancangan Sistem Absensi Berbasis Global Positioning System (GPS) Pada Android 4.x," Semin. Nas. Teknol. Inf., pp. 4-9, 2013.

[4] S. Sandiwarno, "Design Model of Payroll System Integrated with Attendance System at PT. XYZ,” Int. J. Comput. Tech., vol. 5, no. 2, pp. 23-27, 2018.

[5] R. H. Gunawan, D. Rahadian, and Y. Purwanti, "Pembuatan Absensi Berbasis Android Menggunakan Metode Waterfall Untuk Program Studi Pendidikan Teknologi Informasi Ipi Garut," GUNAHUMAS J. Kehumasan, vol. 2, no. 1, pp. 317-328, 2019.

[6] K. Widhiyanti and A. N. D. Soetarmono, "Perancangan Aplikasi GEO-Location Sharing Dengan Location Based Service Pada Sistem Operasi Android," Teknika, vol. 3, no. 1, pp. 1119, 2014, doi: 10.34148/teknika.v3i1.16.

[7] A. Husain, A. H. A. Prastian, and A. Ramadhan, "Perancangan Sistem Absensi Online Menggunakan Android Guna Mempercepat Proses Kehadiran Karyawan Pada PT. Sintech Berkah Abadi," Technomedia J., vol. 2, no. 1, pp. 105-116, 2017, doi: 10.33050/tmj.v2i1.319.

[8] T. Prihatinta and R. D. Wiwoho, "Hubungan Tingkat Kehadiran Melalui Penerapan Absensi Finger Print Terhadap Tingak Disiplin Kerja Karyawan Kontrak Di Politeknik Negeri Madium," Epicheirisi., vol. 1, no. 1, p. 8, 2017.

[9] N. Hermanto, Nurfaizah, and N. R. D. Riyanto, "Aplikasi Sistem Presensi Mahasiswa Berbasis Android,” J. Simetris, vol. 10, no. 1, pp. 107-116, 2019, doi: 10.24176/simet.v10i1.2799.

[10] A. Sasongko, M. S. Maulana, and L. Latifah, "Presensi Karyawan Berbasis Aplikasi Mobile Dengan Filter Jaringan Intranet Dan Imei," Sistemasi, vol. 9, no. 1, p. 92, 2020, doi: 10.32520/stmsi.v9i1.592.

[11] M. D. Radityatama, F. Fauziah, and N. Hayati, "Perancangan Aplikasi Smart Indicator Lecturer Berbasis Android Menggunakan Microcontroller," J. Sist. dan Teknol. Inf., vol. 8, no. 1, p. 121, 2020, doi: 10.26418/justin.v8i1.37940.

[12] P. A. Sunarya, E. Febriyanto, and J. Januarini, "Aplikasi Mobile Absensi Karyawan Dan Pengajuan Cuti Berbasis GPS," CCIT J., vol. 12, no. 2, pp. 241-247, 2019, doi: 10.33050/ccit.v12i2.695.

[13] M. A. R. Sikumbang, R. Habibi, and S. F. Pane, "Sistem Informasi Absensi Pegawai Menggunakan Metode RAD dan Metode LBS Pada Koordinat Absensi," J. Media Inform. Budidarma, vol. 4, no. 1, p. 59, 2020, doi: 10.30865/mib.v4i1.1445.

[14] B. D. Wijaya, E. M. A. Fenty, and A. Fiade, "Implementasi JSON PARSING pada Aplikasi Mobile E-Commerce," J. Pseudocode, vol. 2, no. 1, pp. 1-9, 2015.

[15] M. F. Ramadhani, "Pembangunan Aplikasi Informasi, Pengaduan, Kritik, Dan Saran Seputar Kota Cimahi Pada Platform Android," J. Ilm. Komput. dan Inform., p. 9, 2015.

[16] R. S. Pressman and B. Maxim, Software Engineering: A Practitioner's Approach, 8th ed. McGraw-Hill Education, 2014.

[17] N. Ani, H. Noprisson, and N. M. Ali, "Measuring usability and purchase intention for online 
travel booking: A case study," Int. Rev. Appl. Sci. Eng., vol. 10, no. 2, pp. 165-171, 2019, doi: 10.1556/1848.2019.0020.

[18] A. Bangor, P. Kortum, and J. Miller, "Determining what individual SUS scores mean: adding an adjective rating scale," J. usability Stud., vol. 4, no. 3, pp. 114-123, 2009.

[19] A. Y. Ananta, N. Noprianto, and V. N. Wijayaningrum, "Desain Sistem Smart Attendance Menggunakan Kombinasi Smart Card Dan Sidik Jari," Sistemasi, vol. 9, no. 3, p. 480, 2020, doi: $10.32520 /$ stmsi.v9i3.874. 